\title{
Gender Disparity in Turkish Higher Education
}

\author{
Leyla Yılmaz Fındık \\ Department of Educational Administration Supervision Planning and Economics, Hacettepe University, Turkey
}

Copyright $(2016$ by authors, all rights reserved. Authors agree that this article remains permanently open access under the terms of the Creative Commons Attribution License 4.0 International License

\begin{abstract}
Turkey has been concerned about gender inequality in education for many years and has implemented various policy instruments. However, gender disparity still seems to prevail today. This study seeks to provide an insight to the gender differences in terms of enrollment rates, level of education, fields of education and number of graduates in Turkish higher education. The research was structured as a descriptive study. Being a descriptive study, secondary data obtained from the Council of Higher Education's website (CoHE), http://www.yok.gov.tr/ is used in this research and the present study takes the year of $2014 / 2015$ for the selected criteria but just 2013-2014 as a reference for graduates. With the latest data available, the percentage of gender difference according to the number of both male and female students enrolled in higher education is calculated. Results presented in charts and graphs indicate that Turkey has made progress in reducing gender disparity in higher education while gender disparity is still severe and needs more emphasis.
\end{abstract}

Keywords Gender Disparity, Higher Education, Enrollment Difference

\section{Introduction}

Gender equality is a moral imperative beyond its economic empowerment. Furthermore, it is about fairness and equity and includes many political, social and cultural aspects $[1,2,3]$. Gender equality is a crucial indicator of a country's social and economic development however, development policies and actions do not approve gender inequality and therefore gender disparity will display limited effectiveness as well as serious cost implications [4]. In addition to this, gender disparity in education is still a significant issue worldwide and closing this gender gap is vital for the economic, social and environmental development of a country as greater gender equality may enhance current economic productivity and improve development outcomes [3]. It is also proven that gender equality in education is statistically associated with economic development $[5,6]$. To illustrate, girls with access to education not only advance their career opportunities, life styles, social status but also have an impact on economic growth and social development of the entire nation $[7,8,9,3]$. Besides, studies have documented that the returns of female education are higher than those for males [10] and educating girls is considered one of the most cost-effective mechanisms for advancing the development and growth in a society [9]. Studies indicate that educated girls make valuable contributions to reducing child mortality and fertility, increasing life expectancy; improvement of child's health, schooling and adult productivity; and enhancing community health as well as prosperity $[11,12,13,9,3]$.

Gender equality is high on the agenda of many international education institutions and acts. It is clearly stated that "gender equality, the empowerment of women, women's full enjoyment of all human rights and eradication of poverty are essential to economic and social development, including the achievement of all the Millennium Development Goals." and the following actions are all related to achieving gender equality. "World Declaration on Education for All" and the "Framework for Action to Meet Basic Learning Needs" were adopted by the World Conference on Education for All in which participating countries were committed and to ensuring gender equality in education in Jomtien, in 1990. Ten years later, in the World Conference held in Dakar in 2000, the participants in the World Education Forum made a commitment for the achievement, goals and targets of education for all (EFA), including all individuals in every society [14]. With the goal of attaining gender equality, improving girls' access to higher education is a vital component of promoting development and meeting the Millennium Development Goals (MDGs). It has been declared that gender disparity in primary and secondary education will be eliminated no later than 2005 and it will also be eliminated from all level of education until 2015. 2012 World Development Report underlines the importance of the gender development and evidently states that gender equality is a core goal of development. It is also specified that gender equality enables the enhancement of productivity of the current generation as well as improving development outcomes for the next [3].

Recently, much progress towards gender equality in education has been made in many countries around the world. 
In reference to this progress, it can be said that more girls are now in school compared to 15 years ago [15] and girls outperform boys in some areas of education [2]. Moreover, the developing regions have achieved the target to eliminate gender disparity in primary, secondary and tertiary education [15]; however, the glass is still half-full: women are still left behind men in some countries [2].

In Turkey, equality before the law is stated in the Constitution of the Republic of Turkey which was adopted in 1982 and in 2004 the Republic of Turkey made a commitment to European Union stating to ensure gender equality. During this period, the statement of "Men and women have equal rights. The State has the obligation to ensure that this equality exists in practice." was added to the Constitution of the Republic of Turkey as well. Apart from this, the statement of "Measures taken for this purpose shall not be interpreted as contrary to the principle of equality" was also added to the constitution in 2010. The Constitution of the Republic of Turkey also declared that "state organs and administrative authorities are obliged to act in compliance with the principle of equality before the law in all their proceedings." Gender mainstreaming is another highly emphasized issue in the Ninth Development Plan for 2007-2013 as well as in the Tenth Development Plan of Turkey for 2014-2018, one of the main objectives of which is to empower women in all aspects of social, economic and cultural life [16,17]. In addition to all these regulations, Gender Mainstreaming National Action Plan for the years 2008 to 2013 was prepared to ensure gender equality according to high-level political papers such as the Ninth Development Plan for the years 2007 to 2013; Convention on the Elimination of All Forms of Discrimination against Women; Union Acquis and Millennium Development Goals. The goals of Gender Mainstreaming National Action Plan are to ameliorate gender equality and to improve social, economic and cultural status of women as well as preventing gender discrimination. This Action Plan is considered to be a crucial tool to remove social gender inequality in practice even though gender mainstreaming has been guaranteed in law [18]. Council of Higher Education in Turkey has also placed great emphasis on female access to higher education in the Strategic Plan 2007-2013 [19]. By taking all these measures into consideration, it can be concluded that Turkey has made both international and national commitments to ensure gender equality as well as implementing various policy instruments to eliminate gender disparity. However, this study aims to investigate whether or not, gender inequality still prevails today in Turkish higher education.

\subsection{Objectives}

Given the importance of gender equality for social and economic development, the study focuses on gender disparity in Turkish higher education. The study aims to investigate whether or not gender equality in higher education has been achieved in Turkey. To meet this goal, the study analyzes the difference between male and female students enrolled in higher education in the last ten years as well as the number of male and female students by field of education, by level of education and by the number of graduates with the reference to the latest data. This research seeks to find answers to the following research questions:

1. Is there a gender difference in total number of male and female students enrolled in higher education in the last ten years?

2. Is there a gender difference in the number of male and female students by level of education in $2014 / 15$ ?

3. Is there a gender difference in the number of male and female students in associate, bachelor and graduate degrees by field of education in 2014/15?

4. Is there a gender difference in the number of graduates in 2013/14?

This study provides a picture of the gender disparity in Turkish higher education in an attempt to address the strategic questions related to the future of Turkish higher education, and to discuss gender disparity in detail with the aim of shedding light on new planning.

\section{Materials and Methods}

The research is a descriptive study and is based on secondary data obtained from the Council of Higher Education's website (CoHE) (http://www.yok.gov.tr/). Percentage and frequency values were calculated from the data received from CoHE. The results are presented in percentages and figures and they are given under the headings of the number of students in the last 10 years, the number of male and female students according to level of education, field of education and graduation rates in higher education with the latest data available. The present study takes the years 2014/2015 as a reference, but just 2013/14 as a reference for graduates. The percentage of gender difference is calculated by using the number of male and female students enrolled in higher education. Positive difference refers that the number of female students is more than that of male students and negative difference refers that the number of male students is more than that of female students for the selected criteria. Negative difference means these indicators must be improved in favour of female students.

\subsection{Results}

The study summarizes the gender differences in Turkish higher education. The number of students and the gender difference in the last 10 years in Turkey are presented in Figure 1. The figure shows the number of male and female students in the last ten years starting from 2004/05. Additionally, differences between male and female students are calculated in percentage for each reference year 


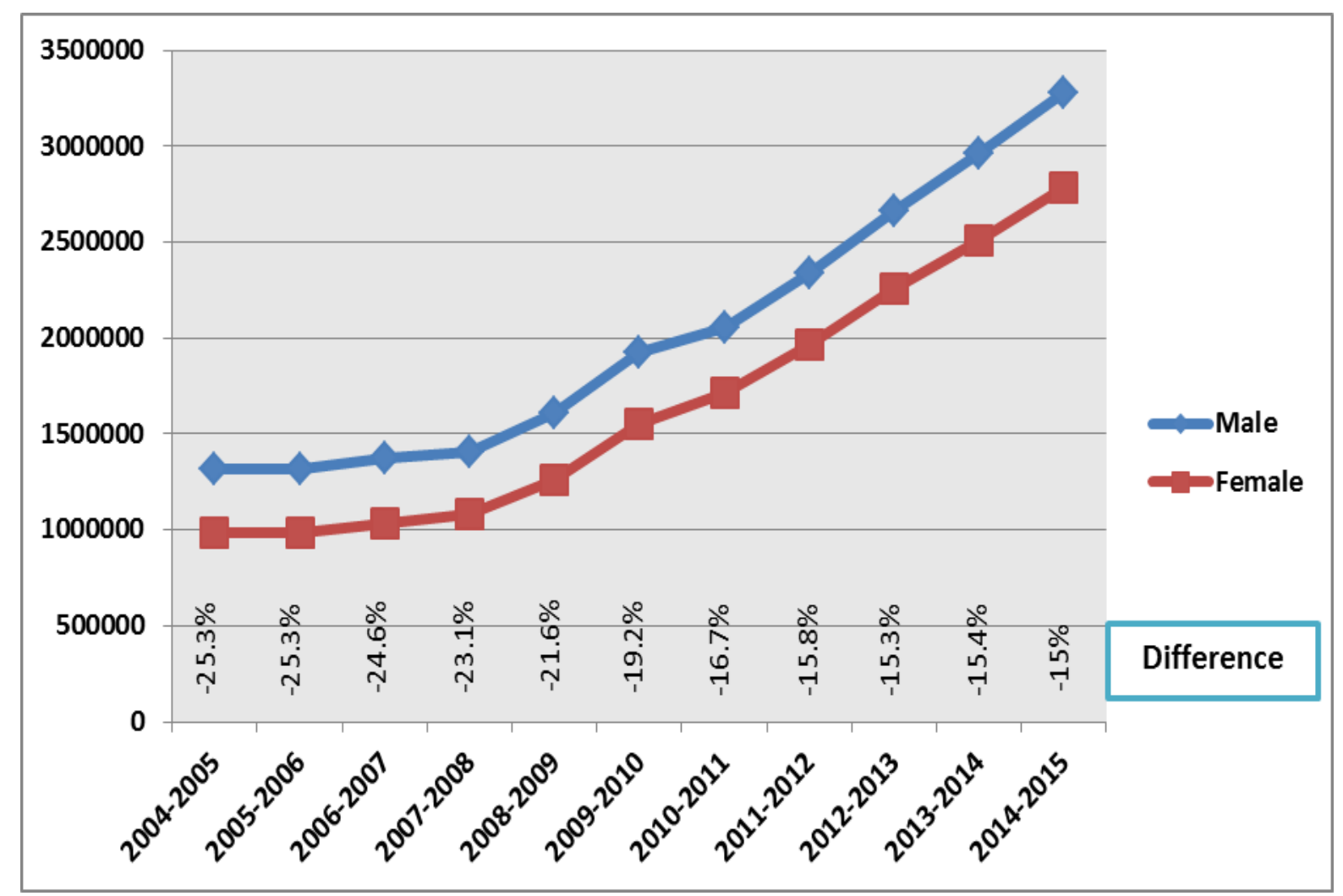

Figure 1. Number of students and the gender difference in the last 10 years in Turkey

The graph shows that the number of both male and female students has increased progressively since 2004-2005; however, the difference between male and female students seems to be prevalent. As can be seen in the graph, $-25.3 \%$ difference in 2004/5 is the highest rate of difference between male and female students in the last ten years. This is followed by $-25.3 \%$ in $2005 / 06 ;-24.6 \%$ in $2006 / 07$ and $23.1 \%$ in $2007 / 08$. This difference tends to decrease gradually since $2004 / 05$ and reaches $-15 \%$ difference between male and female students in 2014/15. In the last ten years, the total number of male students has always been more than female students in Turkish higher education. The decrease in difference seems to be positive in terms of gender equality; nevertheless, the difference is still too much since the difference still exists in the number of students in Turkish higher education.

Figure 2 presents gender difference by level of education with the reference year 2014/15. The difference is calculated by using the number of students enrolled in each level of education in 2014/15 and given in percentage.

The figure shows that $-29.5 \%$ is the largest difference between male and female students in master's degree. The number of male students with a master's degree is much more than those of female students. This is followed by doctorate degree with the percentage of $-28.2 \%$ in $2014 / 15$. It is concluded from the figure that the number of male students in graduate programs is far more than those of the female students. The difference is $-15.6 \%$ in bachelor's degree. The difference between male and female students in associate programs (short cycle tertiary programs) is relatively low with the rate of -10.5 .

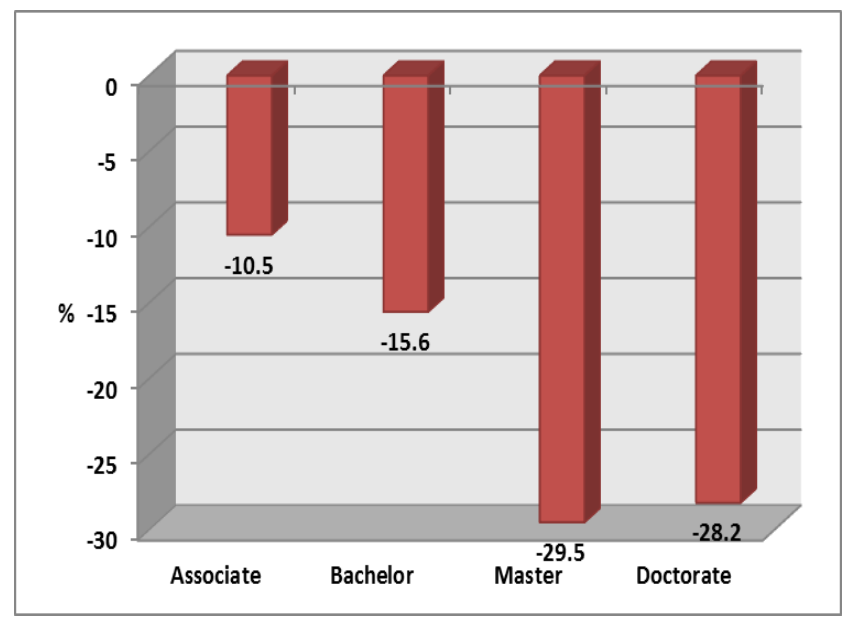

Figure 2. Gender difference by level of education (2014-2015)

Figure 3 shows the gender difference in associate programs by field of education in 2014/15.

The difference between male and female students varies depending on the field of education. Female students particularly in associate programs are overrepresented in education with the highest rate of $70.60 \%$. It can be attributed to the fact that education in these associate programs is designed to train vocational teachers and pre-school teachers and that might be the reason why female students prefer studying at these two programs. Female 
students are also more than male students in health $\&$ welfare associate programs having the rate of $131.9 \%$ and unclassified associate programs have $61.6 \%$ difference. On the other hand, there is a big difference, $-82.2 \%$ between male and female students in engineering, manufacturing \& construction associate programs. This difference is followed by $-60.8 \%$ in sciences, mathematics and computers associate programs and $-40.4 \%$ in services programs.

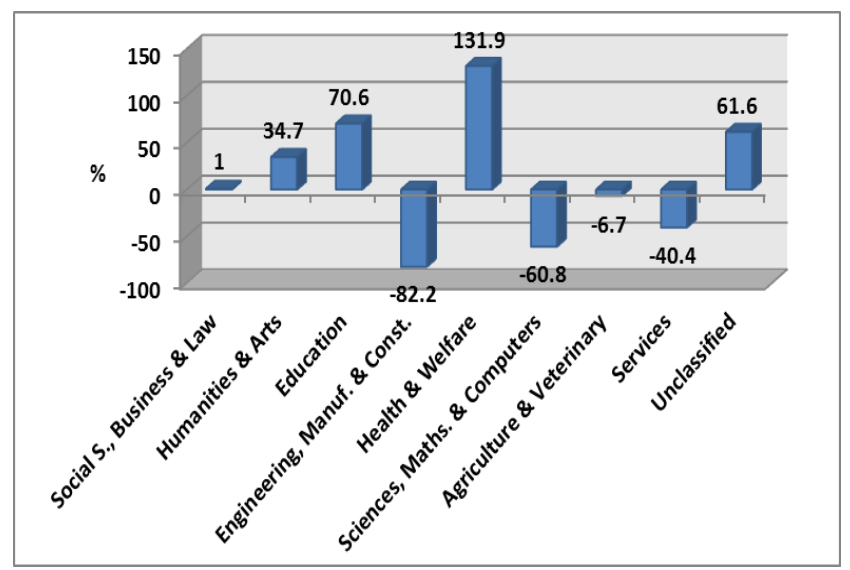

* 7060.3 is divided by 100 and $70.6 \%$ difference in education is presented in the figure.

Figure 3. Gender difference in associate programs by field of education (2014-2015)

The gender difference in bachelor programs by field of education in 2014/15 is presented in Figure 4.

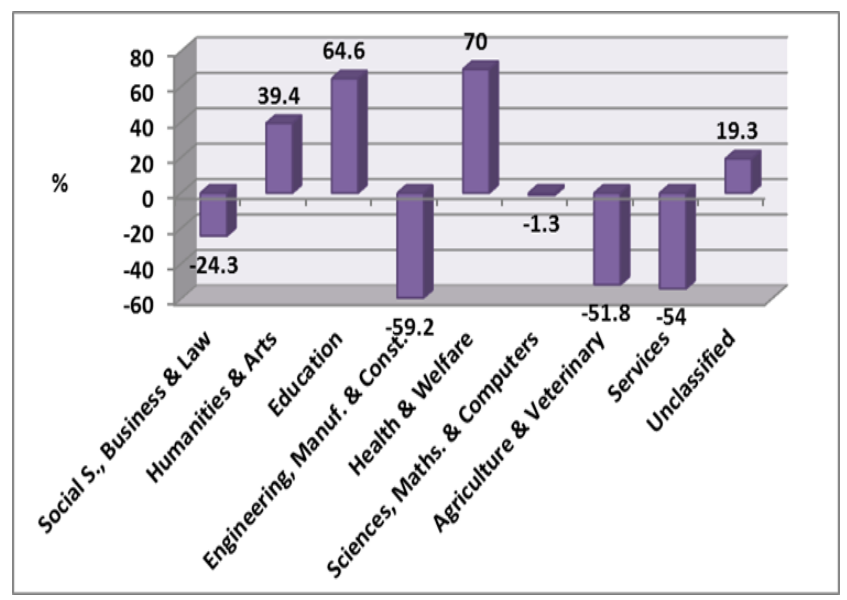

Figure 4. Gender difference in bachelor programs by field of education (2014-2015)

Female students are overrepresented in the field of health and welfare with the percentage of 70 . This is followed by $64.6 \%$ in education and $39.4 \%$ in humanities and arts in bachelor programs in $2014 / 05$. However, there is a huge difference between male and female students in engineering, manufacturing \& construction programs, having the rate of $-59.2 \%$ difference. This difference is $-54 \%$ in services; $-51.8 \%$ in agriculture \& veterinary; $-24.3 \%$ in social sciences, business \& law. Male and female students are almost balanced in sciences, mathematics \& computers in bachelor programs.

Gender difference in graduate degrees by field of education with the reference year 2014-2015 is presented in Figure 5.



Figure 5. Gender difference in graduate degrees by field of education (2014-2015)

In graduate degrees, female students are overrepresented in health \& welfare programs and the difference is $136.7 \%$ and this difference is $8.8 \%$ in education. There are differences between male and female students in the other types of programs in graduate degrees. The difference in the number of male and female students in engineering, manufacturing \& construction is $-56.5 \%$ and this means that male students are more than female students in this program. This is followed by $-49.2 \%$ difference in services programs; $-48.3 \%$ in unclassified graduate programs and $-39.5 \%$ in agriculture \& veterinary. The rate of difference is $-5 \%$ in sciences, mathematics \&computers programs.

Gender differences of graduates by level of education with the reference year 2013/2014 are shown in Figure 6.

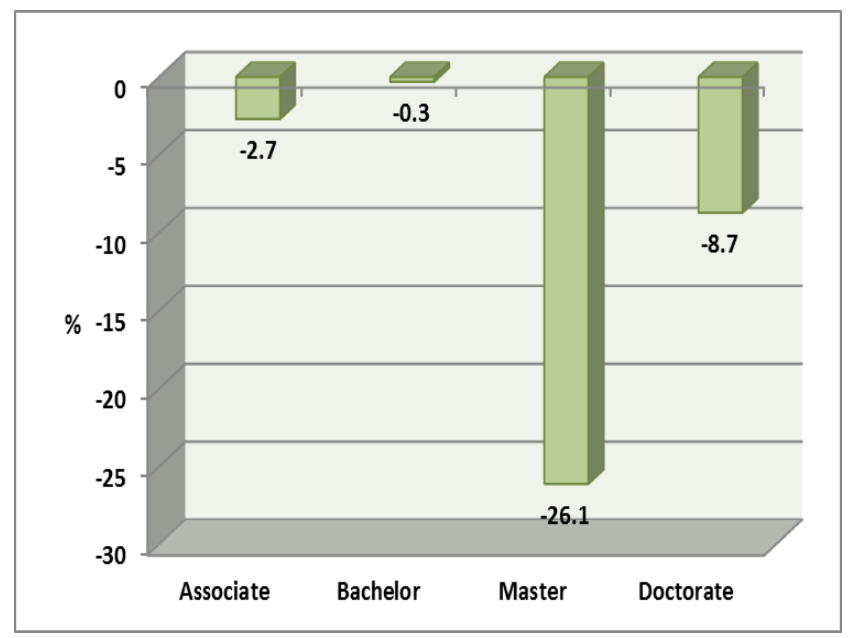

Figure 6. Gender difference of graduates by level of education (2013-2014)

Graduates from master's degree have a huge difference of 
$-26.1 \%$ and this shows that the number of graduated male students is more than that of female students in 2013/14. This difference is -8.7 in doctorate degree and -2.7 in associate degrees. The number of male and female graduates seems to be almost balanced in bachelor degrees.

\section{Conclusion}

The study discussed gender disparity in higher education via some selected indicators in Turkey. Despite the crucial role of gender equality on development, Turkey exhibits gender inequality in higher education but there has been a downward trend in the last ten years.

From the present overview, some remarkable findings come clearly to the forefront:

- The difference between total male and female students enrolled in higher education has still been prevalent since 2004/05. The difference seems to be decreasing and shows a positive action in the last 10 years. However, this positive action is not adequate. The biggest difference is in 2004/05 and the lowest difference exists in the years of 2014/15.

- There are differences in all levels of education in $2014 / 15$. The biggest difference is in master's degree and the number of male students enrolled in master's degree is a lot more than female students. The difference is relatively lower in associate degrees.

- In associate degrees, female students are overrepresented in education as well as in health \& welfare programs however, male students are overrepresented in engineering, manufacturing \& construction and sciences, mathematics \& computers programs.

- In bachelor degrees, female students are overrepresented in health and welfare; education; humanities and arts programs. Male students are a lot more than female students in engineering, manufacturing \& construction; services; agriculture $\&$ veterinary programs with the reference year 2014/15.

- In graduate degrees, the number of female students in health and welfare programs is far more than that of male students. The number of male students is much more than the number of female students in engineering, manufacturing \& construction; services and unclassified programs respectively.

- All in all, female students are overrepresented in education and health programs however male students are a lot more than female students in engineering, manufacturing \& construction in all level of education.

- There seems to be a big difference between the number of male and female graduates from master degree programs. This difference is decreasing gradually in doctorate degree, associate degree and bachelor degree respectively.
Despite the fact that gender equality is one of the core international and national values, the level of gender disparity remains steady in Turkish higher education. Turkey has implemented various policy instruments and has made progress in reducing gender disparity; however, it failed to fully accomplish its goal and could not ensure gender equality in all areas of higher education. The study suggests that despite recent increase in female's enrollment in higher education, which means a positive action, the increase has remained relatively low and not sufficient to eliminate gender disparity in Turkish higher education. Immediate actions on gender equality need to take in Turkish higher education. Turkey must decide on key priority areas and key actions to make progress and foster gender equality. To ensure gender equality, it is essential to target the root causes of gender disparity in higher education.

\section{Acknowledgements}

This study was presented at the $7^{\text {th }}$ International Conference on Intercultural Education "Education, Health and ICTs from a Transcultural Perspective" on 15-17 June, 2016 in University of Almeria, Spain. This study was produced from a project supported by Scientific Research Projects Coordination Unit of Hacettepe University.

\section{REFERENCES}

[1] M. B. Littlefield, D. Mc-Lane-Davison, H. F. O.Vakalahi. Global gender inequality. Encyclopedia of Social Work, p. 1-16, 2015. DOI: http://dx.doi.org/10.1093/acrefore/9780199975839.013.932

[2] OECD. OECD Week 2012 Gender Equality in Education, Employment and Entrepreneurship: Final Report to the MNM. OECD, 2012

[3] World Bank. World Development Report 2012: Gender and Development, Washington, DC, World Bank, 2012.

[4] World Bank. Engendering ICT: Ensuring Gender Equality in ICT for Development. Washington, D.C., 2003.

[5] D. Abu-Ghaida, S. Klasen. The costs of missing the millennium development goal on gender equity. IZA Discussion Paper, No. 1031, 2004.

[6] D. H. C. Chen. Gender Equality and Economic Development The Role for information and communication technologies. World Bank Policy Research Working Paper 3285, 2004.

[7] European Union. Strategy for Equality between Women and Men 2010-2015, European Union, Luxembourg, 2011.

[8] P. Glewwe, Paul, M. Kremer. "Schools, teachers and education outcomes in developing countries," In Handbook of the Economics of Education, ed. by E. Hanushek \& F. Welch, North Holland, 2006.

[9] M. Tembon, L. Fort. Girls' Education in the $21^{\text {st }}$ Century. The World Bank, Washington DC, 2008. 
[10] G. Psacharopoulos. Returns to Investment in Education: A Global Update. World Development 22(9): 1325-1343, 1994.

[11] DFID. Girls' education: towards a better future for all. Glasgow: Department for International Development, 2005.

[12] S. Klasen. Does gender inequality reduce growth and development? evidence from cross-country regressions. Policy Research Report on Gender end Development Working Paper Series, No.7, World Bank, 1999.

[13] Leah Witcher, J. (2009). Forum on Public Policy: A Journal of the Oxford Round Table, 2009 (2), p. 1-28.

[14] UNESCO. The Dakar framework for action. World Education
Forum, 2000.

[15] United Nations. The Millennium Development Goals Report 2015. New York: United Nations, 2015.

[16] Ministry of Development.. The Tenth Development Plan, 2014-2018. Ankara: Ministry of Development, 2006

[17] Ministry of Development.. The Tenth Development Plan, 2014-2018. Ankara: Ministry of Development, 2013

[18] Republic of Turkey Prime Ministry. Gender Mainstreaming National Action Plan, 2008-2013. Ankara: Fersa Ofset, 2008.

[19] Council of Higher Education. Strategies for Higher Education in Turkey. Ankara, Council of Higher Education, 2007. 